\title{
Th' Abstract of All Faults: Antony vs. the Hegemonic Man
}

\author{
RACHAEL KELLY, UNIVERSITY OF ULSTER
}

\begin{abstract}
The story of the lives and deaths of Cleopatra VII of Egypt and her lover, the Roman triumvir Marcus Antonius, have been the subject of considerable mythologisation in the two millennia since their suicides at Alexandria. In recent years, some scholars have noted that the image of Cleopatra has been used, in various texts, to perform cultural anxieties about the meaning of acceptable womanhood. However, whilst there is some evidence (albeit problematic) that the screen Cleopatras of the past forty years have been subject to a recuperation of sorts, there has been no similar recuperation or critical analysis of the image of Antonius (or Antony). This paper seeks to examine the use of Antony to interrogate notions of hegemonic masculinity on screen, through an analysis of five texts covering the years 1934-2007 which feature Antony in a key role. By investigating the opposition of Antony and his performance of deficient masculinity against the recurring figure of the paradigm or hegemonic man, this paper seeks to position Antony as a site for the negotiation and articulation of anxieties about the performance of idealised masculinity.
\end{abstract}

\section{KEY WORDS}

Mark Antony, gender performance, historical films, hegemonic masculinity

\begin{abstract}
If bodies in perspective space appear to be ranged along a continuum from closer to father away, might there not be an equivalent continuum in psychic space? To understand masculinity in terms of others, we need to consider two distinct situations: one in which masculinity is defined vis-à-vis various opposites and one in which masculinity is experienced as a kind of merging or fusion of self with others. We need to understand, not just the 'not me', but the 'partly me' and the 'other mine'.
\end{abstract}

(Smith, 2000, p.104)

The historical figure Marcus Antonius was born in Rome in 82BCE and committed suicide fifty-two years later in Alexandria, following the defeat of his joint expedition with Cleopatra VII of Egypt to definitively settle his power struggle with $\mathrm{C}$ Julius Caesar Octavianus, the grand-nephew and adopted son of Antony's close friend, C Julius Caesar. Hostilities between the two men had been building for over a decade and the escalation to war followed the dissolution of the tentative Triumvirate - a duumvirate since the ousting of its third member, Lepidus, in 36BCE - that had governed the Roman empire since the Battle of Philippi in 42BCE. 
Antonius' close working relationship with Caesar, and his own considerable military and political gift, afforded him a position of relative power over the other members of the triumvirate, which in turn allowed him to select the wealthy east for his third of the empire. A political allegiance with the ruler of Egypt - and the riches at her disposal - whilst almost certainly an attempt to consolidate his significant power-base, has, in the two millennia since his death, become the cornerstone of a mythology that has sought to cast Antonius as Mark Antony, the man who threw away his empire for love.

Antony-as-cipher bears little relation to Marcus Antonius the general and politician. Where Antonius was politically astute, Antony is apathetic, preferring revelry to debate. Where Antonius was judicious in his allegiances, Antony falls helplessly in love with his bewitching Oriental mistress and is unable or unwilling to think or act for himself. Where Antonius was a gifted general, well-loved by his troops and famous for surviving several serious reverses and ultimately turning them to his advantage, Antony is rarely seen in battle and, in his most recent appearances, is given to unpredictable, murderous impulses off the battlefield. The recurring flaws of Antony-as-cipher, indeed, are so predictable that I have elsewhere (Kelly, 2008) argued that Antony-as-cipher is in fact a site of negotiation for contemporaneous masculinities, where hegemonic masculinity finds its reverse image in the man who ought to embody a paradigm but falls short on every count. In this paper, I intend to investigate the cipher further. Antony's gender positioning within the screen depictions of his life should be understood as occupying (or seeking to occupy) Smith's idea of the 'not me' - an avatar of maleness that the spectator should be socio-culturally primed to reject. I want to investigate the screen Antony's position on Smith's continuum of identification/disidentification: in short, the ways in which other performances of masculinity are used to comment on Antony's own deficiencies.

This opposition of the hegemonic versus the deficient is both an amalgamation of several items of Antony's iconography (Kelly, 2008), and a more complex Other-ing of his character from paradigm masculinity. It is strongly rooted in Augustan political expediency, but its manifestation and semiological associations are entirely constructed by twentieth and twentyfirst century gender discourse. Furthermore, it serves not only to interrogate Antony's positioning as cipher, but also Cleopatra's, in that it explicitly questions her response to Antony's emasculating love (and, by extension, therefore, the validity of Antony's decision to allow his love to dictate his policy).

To be clear: Antony's embodiment of feminized (or hyper-masculinized) masculinity is in and of itself sufficient to indict him. However, the screen texts, without exception, have elected to follow the Plutarchian model and underscore Antony's failings by directly opposing his icon against performances of paradigm masculinity. Plutarch, of course, framed his series of Parallel Lives (Bioi Paralleloi) as a collection of dyads in which one particularly praiseworthy individual was contrasted against one particularly worthy of censure: his Life of Marcus Antonius is situated alongside his Life of Demetrius. It follows the standard Plutarchian trope of identifying similarities (albeit sometimes tortuously extracted) in the lives of both men in order to illustrate the deficiencies in Antony's character, as exposed by his reaction to events, versus the nobility of Demetrius, whose reactions are considered exemplary. Plutarch is referenced by at least two of the texts under analysis - arguably, the two texts making the most strident truth-claims: Cleopatra (1963) and Rome (Season 1: 2005 \& Season 2: 2007) as one of the historical sources consulted during pre-production, and is cited by Margaret George, author of The Memoirs of Cleopatra (on which 1999's Cleopatra is ostensibly based) 
as a source for 'a personal feeling about the characters [Antony, Cleopatra and Julius Caesar].' (George, 1997, p.1136)

Plutarch's importance to the Antonian iconography cannot be overstated. Shakespeare's Antony and Cleopatra, which arguably provides a baseline for all modern receptions of the Antony-myth, is in itself heavily reliant upon the North translation of The Life of Marcus Antonius (effected in 1579). As such, Plutarch's text has pervasively entered Antony's popular cultural lexicon, to the extent that the former has effectively become the most readily recognisable point of reference for the latter. While it may be true that 'Screenwriters almost never read Plutarch,' (Daugherty, 2008, p.144) screenwriters undoubtedly reference Plutarch, at least in part because the cultural reification of Shakespeare has, albeit on a much lesser scale, afforded a certain meta-fame to his sources. 'Plutarch' (as a concept, rather than an historical entity) has thus become a kind of shorthand for historical validity, invoking the name of a highly recognisable ancient source with strong popular-cultural links to Antony as evidence of meticulous historiographical research and a superior claim to historical verisimilitude. All of which, of course, conveniently ignores Plutarch's original moralistic intention and the concomitant ideological positioning of his text.

Nevertheless, whether as evidence of Plutarch's cultural resonance, or simply as an illustration of Antony's failure to perform hegemonic masculinity and his embodiment of feminized or hyper-masculinized masculinity, the appearance of the hegemonic male is ubiquitous to Antony's screen incarnation, and, as such, warrants careful consideration.

The screen texts under analysis, selected from amongst the available English language soundera texts due to their clear opposition of the hegemonic versus the deficient, are as follows:

Cleopatra (1934)

Serpent of the Nile (1953)

Cleopatra (1963)

Cleopatra (1999)

Rome (2005 \& 2007)

The paper will seek to examine the hegemonic masculinities opposed against Antony as they relate to three broad categories. Firstly, I will offer an overview of the texts in question, with a detailed analysis of the avatars of hegemonic masculinities contained within each. This will not include the highly complex interaction of Antony with Julius Caesar, which will take its own category heading, and which will encompass the lion's share of the paper due to its ubiquity and its associated meta-discourses on both men. Finally, I will examine those instances where hegemonic masculinity is configured so as to render its avatars as Antony's rival for Cleopatra's affection. Whilst this group undoubtedly includes Caesar, the complexity of the framework surrounding Antony's rivalry with Caesar warrants its inclusion in the previous section.

\section{THE PARADIGM}

What is the paradigm against which Antony is measured? There is no simple answer. RW Connell calls hegemonic masculinity an 'historically mobile relation' (Connell, 1995, p.77), and, as the meaning of hegemonic masculinity shifts, so does its manifestation in the Others against which Antony is opposed. 
The ghost of Shakespeare pervades each of the texts, and Cleopatra (1934) follows the Shakespearian structure most closely, configuring as paradigm masculinities both Octavian and Enobarbus (who is a key figure in Antony and Cleopatra, but who rarely makes a screen appearance). The presentation of Octavian's performance of masculinity as paradigm is extremely unusual. To explain in detail why this should be the case would require considerably more space than is available; however, the general trope is to position Octavian as the quasi-sociopathic political genius - by far the best man to lead Rome out of the chaos of the Late Republic (a chaos which is embodied in Antony and his excessive physical appetites), but a man capable of incredible inhumanity and ruthlessness in pursuit of political equilibrium. In Cleopatra, Octavian is (ahistorically) made older than Antony, which allows him to escape the negative discourse that generally attaches to him when he is a child or a younger man attempting to oust the dashing, adult Antony, and which affords him licence to comment on Antony's profligate, immature behaviour. 'I'm glad he's above something,' he comments dryly, when Antony proclaims himself 'above sleep.'(De Mille, 1934)

Enobarbus, however, is given the most damning indictment on Antony's deficiencies, by virtue of being his close friend and confidant throughout the narrative. Enobarbus, in common with most paradigm masculinities, spends his screen time attempting to correct Antony's deficiencies and save him from the ruin to which they are inexorably leading. That he ultimately fails to do so is configured not as the fault of Enobarbus, but as the fault of Antony, and of Cleopatra's manipulations, which Antony's gender positioning has left him helpless to avoid: 'You, who might have been the world's great man, ends all for a woman,' he says. 'For that, I give you the world's contempt.' (De Mille, 1934)

Serpent of the Nile (1953) creates the fictional character of Lucilius, again a close friend of Antony, who again attempts to force Antony to resist the gender reversal imposed by Cleopatra. Lucilius, however, occupies the position of love rival, and will be discussed in further detail under that heading.

Cleopatra (Roddam, 1963) presents two paradigm masculinities: one explicitly hostile (Apollodorus, who also acts as love rival, and who is discussed below), and one sympathetic. Rufio is less tolerant of Antony's shortcomings than Enobarbus or Lucilius - being an advisor inherited from Caesar rather than specifically a friend of Antony - but nevertheless remains loyal to him, opting for suicide when it becomes clear that Antony's decisions have made ignominious defeat inevitable. Rufio speaks against Antony's decision - a response to Cleopatra's request - to fight the Battle of Actium at sea, and silently allows Antony to drunkenly abuse him while he stands his ground with quiet dignity. It is also Rufio who implicitly confirms Antony's assessment of himself as Caesar's inferior:

ANTONY: I wish I had not drunk so much today.

RUFIO: So do I.

ANTONY: Do I trouble you, Rufio?

RUFIO: Yes you do.

ANTONY: I'll wager you never found Caesar befuddled by wine. Nothing, no-one ever befuddled Caesar. 
Cleopatra (Roddam, 1999) employs the trope of the protector as avatar of paradigm masculinity. Unusually, although not uniquely, the paradigm is embodied in a non-Roman: Cleopatra's Greco-Egyptian physician, Olympos. Olympos is fiercely loyal to Cleopatra, but is reticent about her motivations and is much more politically astute than either she or Antony. $\mathrm{He}$ is able to correctly predict the outcome of her manoeuvring, which is rarely what she expects, and is therefore better placed than she to offer a commentary on Antony. Having been proved right many times in the past, and been consistently ignored by Cleopatra, his assessment of Antony carries much greater weight than hers:

CLEOPATRA: He's wonderful with [Caesarion].

OLYMPOS: I shouldn't wonder - he's a child himself.

CLEOPATRA: You would do well not to disparage Antony in my presence.

OLYMPOS: Are you that much in love with him? Is your judgement that clouded?

Rome (2005 \& 2007) is unusual in that paradigm masculinity is embodied in two men, but neither man alone exhibits paradigm masculinity. Vorenus is the emotionally appropriate family man, the protector, who resorts to excessive appetites only in extremis; however, he is also often cold, emotionally unavailable, socially awkward, and tends towards pride and selfrighteousness. Pullo is warm, loyal, bluff and honest; he loves easily and constantly, and is extremely likeable. He is also sexually excessive, drunken, impetuous, and has a tendency towards unpredictable outbursts of violence. It is only when considered as a dyad that the two men achieve the paradigm. That said, the two are closely connected by the text: their narrative arcs generally involve each other, whether physically or referentially, and where their nonparadigmatic behaviour occurs, it is addressed and recuperated by the other. As Vorenus is more closely affiliated with paradigmatic qualities such as honour and restraint, both of which Antony lacks, commentary on Antony's deficient behaviour - which closely follows Pullo's, but without the recuperating dyadic structure - is generally given to him. Throughout the twenty-two hour run-time, this commentary is too extensive to detail in full; however, one of the most compelling instances occurs towards the end of Season 2, immediately following Antony's death. Vorenus has held his peace during his sojourn in Alexandria, registering his disapproval with Antony's increasingly profligate behaviour through his refusal - at the risk of incurring Cleopatra's wrath - to adopt Egyptian dress or mannerisms, and by gesture and loaded glares, yet he remains loyal to Antony, ultimately helping him to end his life when it becomes clear that this is Antony's only remaining option. As Antony lies lifeless on the floor, Vorenus silently replaces his Egyptian clothing with the uniform of a Roman general, wipes the make-up from his face, and seats him on his throne with his helmet under his arm. Without a word, Vorenus has underscored Antony's deficient masculinity by re-masculinising him once he can no longer resist. (BBC/HBO, 2007)

\section{ANTONY AND CAESAR}

Caesar's narrative positioning unquestionably possesses disproportionate weight in these texts as regards the other paradigm masculinities against which Antony is compared. This is not to suggest that Caesar occupies an exclusive position within any narrative; on the contrary, as we have seen, his is rarely the only performance of masculinity against which Antony is measured. It is, however, the most pervasive and, arguably, the most significant. 
Why has Caesar come to occupy such a privileged position? Maria Wyke, in Julius Caesar: A Life in Western Culture asks the same question of Caesar's prodigious body of appearances in western popular culture in general, and answers it thus:

Caesar's exceptional talents, his actions, and his murder, as they figure in many ancient narratives, all assist in the process of turning the Roman dictator into an embodiment of a profound transformation in the history of Western civilisation from republic to empire. Caught on the threshold of epochal change, Julius Caesar is also deeply implicated in it. Consequently, his biography has taken on monumental dimensions, and matured into a foundational and formative story. It has possessed an extraordinary and lasting appeal because his image has not been fixed... Even from the time of his own writing about himself, Julius Caesar's life has been arranged, fictionalized, and sensationalized so as to become a set of canonic events and concepts whose telling reveals much more than just the minutiae of one individual's existence. Julius Caesar was a Roman leader of flesh and blood who existed in real time. He is also a quasi-mythic protagonist in the development of Western culture.

(Wyke, 2007 p.1)

Caesar's quasi-mythic status, of course, is as dependent on his reception in popular culture as his reception in popular culture is dependent on his quasi-mythic status. As much as Antony or Cleopatra, Caesar has become a cipher, adaptable to the needs of the parable in which he figures; adaptable to the mores and expectations of the culture that receives him. Throughout the course of her book, Wyke details at length the various uses to which the Caesar-icon has been put throughout the ages, summarised in her introductory paragraph:

Whether as a founder or destroyer, Julius Caesar's life has become a point of reference from which to explore concerns about conquest and imperialism, revolution, dictatorship, liberty, tyranny and political assassination. Used as a model or an antimodel for warfare and statecraft, he has also been invoked to pose questions about more personal merits (such as audacity, risk-taking, courage and glory, leadership, good fortune and fame, even immortality) and about personal failings (such as arrogance, ambition, extravagance, lust and cruelty).

(Wyke, 2007, p.1)

As Wyke notes, Caesar occupies a particularly recognisable position in western culture and, as such, has been used as a vehicle for the examination and negotiation of socio-political concerns. However, although critical to understanding his reception in these screen texts, it would be simplistic to regard him as solely in these terms. There are a number of reasons for this. Firstly, although ancient Rome is commonly used as a site for the articulation of US anxieties about empire building, where the imperial/democratic didactic is invoked within any screen text, the narrative is overwhelmingly played out in the Christian era, with the lines clearly demarcated between the might and decadence of Imperial Rome, and the heroic, nonRoman Other (performing American republican ideals) (Joshel, et al., 2001). The preChristian setting of the Caesarian narrative muddies the water somewhat and identification is considerably more fluid. Rome, absolved of its habitual censure by dint of not yet having sunk into the depravity of empire, represents a troubling 'partly-me' in the body of Caesar (and, later, Antony) and a more stable 'other-me' in the body of paradigm masculinity.

The second reason is Caesar's function as one half of the Caesar/Antony dyad. Caesar's positioning - and his performance of quasi-hegemonic masculinity - relative to Antony's considerably mitigates his ideological instability and, as such, considered in conjunction with his cultural privilege, suggests that the socio-political concerns that have discursively attached to him are only part of the story. 
There are three distinct elements to the manifestation of this dyadic relationship. Briefly, they are as follows:

- The division of the narrative in such a way as to emphasise the importance of Caesar to the historical record, and to de-emphasise Antony's contribution

- The configuration of Caesar as 'father' and concomitant designation of the Caesar/Antony dyad as a pseudo-Oedipal drama

- The non-diegetic 'baggage' brought to the text by casting decisions vis-à-vis Caesar and Antony

\section{NARRATIVE DIVISION}

The shift in emphasis is a question of mathematics, and their inappropriate application to the narrative arc. Simply put, the liaison between Caesar and Cleopatra lasted no more than three and a half years (from the autumn of 48 BCE, until his assassination on 15 March 44 BCE), whilst the liaison between Antonius and Cleopatra lasted eleven years (from mid- to late-41 BCE, until their deaths in August and September 30 BCE respectively). Historical dates notwithstanding, those narratives which choose to feature both affairs without exception allot either equal run-time to both $(1934,1963$; arguably also 2005-7, or else greater run-time to the Caesar/Cleopatra liaison (1999).

Clearly, given the considerable disparity in the historical lengths of both affairs, this disproportionate allocation of screen time inherently privileges Caesar by allowing his actions in the last four years of his life to be more closely examined. By contrast, the final eleven years of Antony's life must necessarily be edited by almost two thirds to balance the first act. Furthermore, Caesarion, Cleopatra's son by Caesar, functions as a measure of elapsed screen-time: as his birth is invariably shown (when he features in the narrative - as in 1963, 1999, and 2005-7), his screen age allows the audience to roughly calculate the passage of years within the diegesis. Screen Caesarions never age beyond perhaps ten years (in 20057), and in 1963 and 1999 they appear younger still at the close of the narrative (perhaps seven and four years respectively). The historical Caesarion, by contrast, was seventeen years old and had just celebrated his coming-of-age when he was assassinated on the orders of Octavianus in the weeks following Cleopatra's death. By confining him to childhood, the narrative specifically seeks to apportion a shorter diegetic length to the Antony/Cleopatra liaison, and to signpost it as such.

The division of run-time is further problematized by the fact that many of Antonius's greatest achievements are complex in construction and defy simplistic exposition - to appreciate, for example, the subtleties of his political manoeuvring in the aftermath of Caesar's assassination would involve the allocation of considerable screen time and a prohibitive amount of narrative explanation, particularly given the compression already required to make his story fit the two-act structure. It is also the case that, unlike Caesar, Antony won no battles that directly impact upon Cleopatra's story; indeed, the battles that they fought together - Actium and the final battle of Alexandria - entailed catastrophic losses to their forces and ended in either defeat or retreat. As such, Antony's screen incarnation cannot help but be diminished by the presence of Caesar, even after the latter has left the narrative - indeed, two of the texts (1963 and 1999) have Antony specifically reference his late colleague, usually in relation to Antony's failure to match his exacting standards, ensuring that the ghost of Caesar (and Caesar's performance of masculinity) continues to implicitly critique Antony from beyond the grave. 


\section{CAESAR-AS-FATHER}

Caesar's posthumous presence is an element of the Oedipal dynamic that informs his relationship with Antony, and that is worth expanding upon here, both because it is critical to the configuration of Antony's narrative arc, and because it considerably mitigates the unstable ideological ground that Caesar occupies.

The trope is persistent, and is regularly used to define the dynamics of his relationship with Antony, by reconfiguring it as a pseudo-Oedipal drama. Cleopatra (1963) and Cleopatra (1999) use this trajectory most explicitly, whilst Rome (2005 \& 2007) is less overtly Oedipal but retains an element of the putative father-son drama. I will return to these texts in a moment. First, however, I want to examine the configuration of Caesar-as-father within the body of texts as a whole.

Caesar's authority is repeatedly underscored in explicitly gendered terms throughout his screen incarnations, usually from his first appearance within the narrative. Thus Cleopatra (1934) introduces him in a scene which affiliates him with the masculine business of empire: Cleopatra arrives at the palace of the Ptolemies, disguised in her ubiquitous carpet, to discover Caesar deep in political discussion with his generals. Her stated aim is to use her feminine wiles to ally herself with him, but she finds that he is not easily distracted by whimsy; he ignores her as she perches on his knee and continues to work, and it falls to Apollodorus to prompt her to discuss territorial interests in India with him in order to get his attention. 'It seems strange to see you working,' she says:

CLEOPATRA: I've always pictured you fighting - or loving

CAESAR: I've had some experience with fighting.

CLEOPATRA: But none with loving?

CAESAR: Well - not with pretty little queens.

(De Mille, 1934)

Caesar's dialogue has not only aligned him with the masculinised world of politics and battle, but it has also allowed him to distance himself from the superficial, apolitical world represented by Cleopatra. The reductive nature of the 'pretty little' on the potentially political ('queens') allows Cleopatra to be affiliated with the feminine preoccupations of love and looking pretty for her man; that it is Caesar who has made this reductive statement allows him to disavow the feminine world and firmly ally himself with the business of empire. The opposite is the case for Antony, who is introduced to the screen surrounded by women and physically separated from the politicised males in the scene. That Antony shuns the political in favour of the superficial is further emphasised by his offhand reply to Octavia's suggestion that, since he has been out all night, presumably drinking, he should now return home and sleep: 'Sleep?' he scoffs. 'I'm above sleep, my beloved wife.' Octavian's dry rejoinder establishes Antony's position within the text: 'I'm glad he's above something.' (De Mille, 1934) The distinction is clear: Caesar is the statesman, concerned with the business of empire, the hard-working patrician who immediately and innately adopts the position of superiority. Antony is the profligate party-boy, more comfortable in the company of women than men, and no match (as it will transpire) for Cleopatra's wiles. 
Serpent of the Nile (1953) is unique in featuring Caesar only as a corpse in the opening scene, and, as such, his ghost is absent from later assessments of Antony's masculinity. Rome (2005 $\&$ 2007) elides the specifically Oedipal, but makes manifest Antony's reliance upon Caesar's superior political and diplomatic ability; throughout Season 1, Antony's judgement is repeatedly contrasted with Caesar's and found wanting, and, in Season 2, Brutus verbalises this trope, saying of Antony, 'He's a vulgar beast. Without Caesar he will destroy himself soon enough.' (BBC/HBO, 2007.1) Elsewhere, however, the Caesar-as-father trope is configured more explicitly, by virtue of physically displaying the drama of the father-son conflict on screen. Cleopatra (1963) and Cleopatra (1999) both employ this configuration.

The mechanism by which this is achieved is twofold. Initially, dialogue is used to implicitly bind Antony to Caesar during the first act: Cleopatra (1963) has Cicero refer to Antony as 'a part of Caesar', whilst Cleopatra (Roddam, 1999) has Antony himself express his admiration for Caesar in distinctly filial terms:

CLEOPATRA: And you? Do you distrust him?

ANTONY: Me? No. I love him. He is greatness itself.

Later, as Antony relaxes with Cleopatra at Caesar's Roman villa, his dialogue anticipates the second act of the Oedipal drama. 'I've fought hundreds of men in my time, but I must say, your presence disarms me,' he tells her. 'I envy Caesar.' (Roddam, 1999) This envy is critical in establishing the tension between Antony-as-son and Caesar-as-father; Antony covets Cleopatra, configured as Caesar's reward for appropriate performance of masculinity ('Beloved of the gods, to have you as a prize,' notes Antony just a moment later in the scene). After Caesar's death, Antony-as-son must struggle to fill his putative father's place and establish himself as a worthy successor, not only to Caesar's political dynasty, but to the love of Caesar's mistress. That he falls short of the former is used to underscore his unsuitability to the latter, and it is Cleopatra's failure to recognise this that comprises her tragic arc. Whatever her response to his deficiencies, the narrative didactic remains - Caesar-as-father achieves epic success as leader and lover, Antony-as-son cannot measure up to either, and the echo of the first act hangs heavily over the second. Antony himself explicitly expresses this concept in both texts. From Cleopatra (Mankiewicz, 1963):

ANTONY: Be braver than the bravest, wiser than the wisest, stronger than the strongest, still no Caesar! Do what you will, Caesar's done it first and done it better, ruled better, loved better, fought better! Run where you will as fast as you can, you can't get out! There's no way out! The shadow of Caesar will cover you and cover the universe for all of time. 'Whatever you like,' you said in Rome. 'Come to Alexandria whenever you like.' 'Now - tonight,' I said. 'I would like to come tonight.' To bow to the throne on which Caesar put you, to talk of a new treaty, Caesar's can't be improved: copy it. Of Caesar's son. Of the dream you shared with Caesar that still fills your life. Alexander's design for a world to be ruled by you and Caesar! Where's Antony? Where is Mark Antony? Antony the great, the divine Antony? Here. He's.... here. One step behind Caesar. At the right hand of Caesar. In the shadow of Caesar. Tell me - tell me how many have loved you since him? One? Ten? Anyone? No-one? Have they kissed you with Caesar's lips, touched you with his hands? Has it been his name you've cried out in the dark, and afterwards, alone, has he reproached you, and have you begged forgiveness of his memory?

CLEOPATRA: You come here, then, running over with wine and self-pity, to conquer Caesar? 
Likewise, in Cleopatra (Roddam, 1999):

ANTONY: Grovel? I grovel before no man! And no woman!

CLEOPATRA: Then be strong! Be like Caesar!

ANTONY: I am not Caesar!

CLEOPATRA: No. You're not.

ANTONY: Do you feel this beating heart? That's life you feel! Not a dead king, not a memory, that's me! Mark Antony. Here with you. Right now.

He tries to kiss her, and Cleopatra snaps, 'I'm not your sport, general! Now go away!' His response is to smash the bust of Caesar that rests beside her bed and passionately embrace her. The trajectory is Oedipal only in the sense that it rejects the father through the conquest of the father's sexual property (an attempt to read Cleopatra as mother-figure to Antony is not supported by the text); however, it is key to understanding the authority of Caesar over Antony and Antony's failure to perform masculinity to the standard set by his father-figure.

\section{CASTING CAESAR AND ANTONY}

Caesar's authoritative positioning is reinforced to a large extent by the non-diegetic baggage brought to the screen by the actors selected to embody him. These are as follows:

Cleopatra $(1934)$
Serpent of the Nile (1953)
Cleopatra $(1963)$
Cleopatra $(1999)$
Rome $(2005 \& 2007)$

At the most basic level, the casting mirrors the historical disparity in age between Antonius (who was born in $83 \mathrm{BCE}$ ) and Caesar (who was born in $100 \mathrm{BCE}$ ). Most pairs of Antony/Caesar casting decisions loosely conform to this disparity. A number of factors within the text's diegesis, however, complicate an attempt to read the casting in such simplistic terms.

Firstly, it is important to consider the calibre of the actors in question: the list largely comprises a series of high-profile actors with a visible, recognisable body of screen work to their name at the time of their casting. Although (importantly) most have appeared as the romantic lead at some point in their career, at the time of casting they are more visible as character actors, known for quality, prestige productions and often perennially identified with a key iconic role (Harrison as Henry Higgins; Dalton as Bond). Essentially, they represent prestige casting - in that they evidence a conscious effort to fill the role with an actor of presence and visibility - but also hierarchical casting - in that the role of Antony is designed to usurp Caesar's position as romantic lead, as evidenced by the casting of younger actors with much higher contemporary visibility and romantic appeal. Witness the casting of Richard Burton against Rex Harrison in 1963; likewise, Billy Zane was fresh from appearing in Titanic when he was cast alongside Timothy Dalton - still best known for the Bond movies of the 1980s - in 1999's Cleopatra; and in Rome, James Purefoy, whose most visible roles 
have been almost exclusively predicated on his physical attractiveness, plays opposite Ciarán Hinds, who is best known for high-profile prestige productions but, Persuasion (1995) aside, has rarely featured in a romantic role. At the most simplistic level, Antony is cast with an eye on the box office; Caesar with an eye on the reviews. Whilst this might seem to reduce the overall importance of Caesar to the narrative imperative, two factors problematize this conclusion: firstly, while Caesar is not cast specifically in terms of his romantic appeal to the primary movie-going demographic - the under-30s (Belton, 1994, p. 304) - the above selection of actors have enjoyed considerable screen visibility at the time of their casting, which is in and of itself indicative of their narrative importance.

Secondly, whilst the casting of Antony undoubtedly reflects an effort to position him as a figure of desire, this effort also carries with it the slightly vacuous subtext of 'heart-throb', particularly when opposed against the 'prestige' positioning of Caesar. This is a similar discursive mechanism to that which has traditionally been employed to diffuse Cleopatra's political threat: by making her beautiful, aligning her attraction with femininized domestic concerns (the aesthetic rather than the political) rather than the masculinised public sphere, her political threat is contained and made safe. Cleopatra is regularly described as 'pretty' or 'beautiful' or shown exercising a feminine concern with cosmetics or appearance (not only in her film incarnations, but throughout her popular cultural reception); likewise, Antony is repeatedly referred to (or shown) as physically attractive to the opposite sex and/or unduly concerned with his physical attractiveness - in Cleopatra (1963), in a neat reverse of the traditional trope (most likely apocryphal, in any case), it is Antony who is shown bathing in asses's milk, expressing curiosity as to whether it or cow's or goat's milk might be better for softening the skin.

The aestheticizing of the male body, of course, invokes different dynamics to the aestheticizing of the female, and it is also true that the toga epic has traditionally been a vehicle for the 'safe' display of male flesh (Fitzgerald, 2001). However, the presumed anxiety engendered by this homoeroticisation of the gaze is conventionally diffused by realigning the male body on display with hegemonic masculinity, either by presenting it in action (usually violent action) or by forcing it to suffer. Fitzgerald explains it thus:

There are two contrasted spectacles of manhood in the toga movie: the armor-clad legions tramping in invulnerable synchrony across the screen and the single, semi-naked man raised on a cross to die or displayed in an ecce homo.

(Fitzgerald, 2001, p.42)

Antony is displayed as neither, provoking the conclusion that the display of his flesh is made safe by invoking a gender positioning that disavows homoerotic anxiety. In short, Antony is a safe subject for the gaze because he is not a 'real' man.

It is simplistic, of course, to directly equate physical attractiveness with vacuity or lack of intellgence, and to do so would over-extend my argument; however, such a semantic link is deeply embedded in the collective psyche, and is universally associated with gender stereotypes (Schipper: 2006, for an overview of the pervasiveness of the trope). Such a semantic system inevitably commodifies and assigns value to the individual body on the basis of an assumed brain/beauty dichotomy. Caesar may be physically attractive, but this is not the primary source of his value - his intellectual capacity outstrips his physical attractiveness, which is in line with a hegemonic performance of masculinity. By casting Antony from a pool of actors primarily valued for their physical attractiveness, the implicit corollary is that their attractiveness is their primary commodity. The derogation of Antony's intelligence an 
element of the feminizing process, of course, but, critically, it exists in a positive feedback loop with the casting decision: selecting an actor for his romantic appeal invariably rests disproportionately on his physical appearance over any other consideration, which ensures that Caesar, selected for his non-diegetic prestige, achieves a position of intellectual superiority before the credits even roll.

\section{ANTONY'S LOVE RIVALS}

Antony's relationship with Cleopatra, as we have seen, is informed by a pseudo-Oedipal trajectory, describing the son's attempts to exorcise the ghost of Caesar-as-father. The importance of this trajectory varies from text to text; however, it is almost ubiquitous. Other texts go further and institute a living rival for Cleopatra's affections, whose performance of hegemonic masculinity throughout the narrative creates an implicit commentary on the gender positioning enacted by effectively cuckolding Antony.

The trope appears in the following two texts:

\section{Serpent of the Nile (1953)}

Lucilius is Antony's close friend and confidant; however, Antony is unaware that he and Cleopatra were formerly lovers, and that their relationship ended when Lucilius became disgusted with Cleopatra's manipulative scheming.

\section{Cleopatra (1963)}

Apollodorus is Cleopatra's faithful slave and constant companion, who confesses his love to her shortly before her death. The original cut of the movie included a sequence making explicit reference to a sexual relationship between Cleopatra and Apollodorus, but this was excised from the theatrical release. (Buselink, 1988, p.7)

To be clear: Antony's love rivals are an extension of the positioning of hegemonic masculinities against Antony's performance of masculinity, but they go above and beyond this. While the hegemonic masculinities offer an implicit (or explicit) critique of Antony's deficiencies, they are not generally positioned within any scale of reward/punishment. Where the hegemonic masculinity acts as a love rival, however, Antony is effectively penalized for his deficient performance by being stripped of the heterosexual union that is conceived of as both the embodiment of and the reward for hegemonic masculine performance.

If sexual prowess is traditionally configured as a marker for hegemonic masculinity, it is notable that the most recent text under analysis, Rome - which specifically pathologizes excessive sexual appetite - does not seek to oppose a hegemonic masculinity against Antony using the love rival trope. Whilst Octavia, after her marriage to Antony, continues her affair with Agrippa - who certainly manifests several characteristics of the hegemonic man - their relationship does not support a reading under the terms of the love rival trope, for two reasons. Firstly, Antony and Octavia are an entirely reluctant couple and neither one is invested in the relationship, to the extent that both carry on extra-marital affairs until Antony is forced out of Rome by Octavian. Secondly, Agrippa's status as hegemonic is problematized when he fails to rescue Octavia - as she expects - from house arrest under Octavian's orders. Octavia reveals in anger that she is pregnant, but she is unsure as to whether the child was fathered by Antony or Agrippa. Agrippa's failure to rise to the hegemonic function of family man is underscored by Octavia's parting words to him, after he 
has asked about the paternity of her unborn child: 'Who knows? Neither man is worth a brass obol, so what matter?' (Season 2, 2007). Cleopatra, on the other hand, is apparently sexually faithful to Antony, and her sexual duplicity is enacted upon Caesar. To return to Connell's idea of hegemonic masculinity as an 'historically mobile relation' (Connell, 1995, p.77), it is revealing of the paradigm shift in hegemonic masculinities embodied in Rome that Antony is emasculated not by his forfeiture of the heterosexual union, but by his inability to copulate appropriately.

Antony's love rivals, on the other hand, inhabit a more essentialist mode of performing masculinity. Lucilius and Apollodorus have little in common as avatars of hegemonic masculinity - Lucillius is a Roman general and close friend of Antony's, while Apollodorus is an Egyptian slave (both of which terms are closely affiliated with the feminine in Roman discourse) and antagonistic towards Antony from the outset - but both are conceived of in relation to the archetype of the emotionally reserved, physically powerful protector.

Apollodorus is concerned with protecting Cleopatra, but, no less significantly, Lucillius is concerned with protecting Antony. That Cleopatra does not require protection is symbolic of her gender position in Serpent of the Nile - her narrative positioning is supremely unsympathetic and her downfall is therefore represented as to be desired. Antony is here cast as the victim of her caprice: subject to excessive physical desires (lust and alcohol abuse), he is inherently manipulable and requires the intervention of hegemonic masculinity, which, from its position of appropriate gender performance, is able to perceive the gender reversal being enacted upon Antony.

Throughout the narrative, 'love' is used as a marker of gender performance and relative power. Cleopatra is masculinised by her failure to love appropriately: she loves Lucilius, but is not prepared to prioritise the personal over the political. 'I have no choice but the lover of my heart must be last,' (Castle, 1953) she tells him. Her enduring love for him, however, is not reciprocated; embodying the paradigm, he is disgusted by her disavowal of the feminine business of love, and he thus exercises a power over her that she is not able to match (and which she ultimately seeks to negate in an abortive attempt to have him killed). Lucilius' ability to repudiate love where there is a clear danger that love might emasculate him explicitly marks him as Antony's opposite: Antony's failure to prevent the gender reversal enacted by excessive love - designated as excessive by Cleopatra's failure to reciprocate, and by Antony's subsequent neglect or disavowal of everything not connected to or benefitted by his love for Cleopatra - becomes the signifier and key marker of his deficient masculinity. Lucilius-as-paradigm has already proved himself equal and superior to Cleopatra by rejecting her love. That her love is available to him and not Antony underscores both the error of Antony's judgement in allowing himself to succumb to (feminised) love, and Cleopatra's disdain for the feminised Antony.

Gender performance, thus essentialised, becomes the touchstone for the opposition of Antony and Lucilius, as the former repeatedly attempts to raise the latter to the paradigm. Antony's ultimate failure to rise is eloquently represented in a sequence shortly before the final Battle of Alexandria where Antony hands over his military cloak to Lucilius. In surrendering an explicit symbol of Roman (masculine) rule, Antony implicitly acknowledges Lucilius' superior performance of masculinity, and his own deficiencies.

The symbolic surrender of masculinity is a trope regularly repeated throughout these texts, and more explicitly configured in Cleopatra (1963). Apollodorus, as we have seen, is an 
unstable avatar of hegemonic masculinity, being in an inferior position to both Antony and Cleopatra, and being himself elided with a discourse of femininity as a slave and an Egyptian. Throughout the text, Rufio is the more obvious paradigm, being Roman, military, and substantially superior in political aptitude. Rufio, however, is denied close access to Cleopatra, and is thus unable to act as love rival.

Whilst the theatrical release, as stated above, excised any explicit reference to a love affair between Cleopatra and Apollodorus, a sequence was shot and later edited out in which their relationship was unambiguously displayed. The ghost of this missing sequence hangs over the release print, investing Apollodorus' close companionship with and protection of Cleopatra with a significance not articulated until he confesses his love to her in a scene shortly before her suicide. It should be noted that Cleopatra does not explicitly reciprocate his love, stating only that she has always known of it, whereas she does express her love for Antony on several occasions; however, 'love' and the ability to love appropriately are again used as markers for appropriate gender performance. Early into her relationship with Antony, Cleopatra expresses her reservation with the extent of Antony's love for her:

ANTONY: I have only one master - my love for you.

CLEOPATRA: No - your master must not be love. Never love. Give yourself to love and you give yourself to forgetfulness - of what you are and who you are and what you want.

(Mankiewicz, 1963)

She is later able to recuperate the feminine position somewhat by revoking her earlier statement as he attempts to disavow his: 'How right you were. If love is your master, anyone, anything... never love.' (Mankiewicz, 1963) However, his statement is prompted by bitterness that his great, romantic gesture - abandoning the Battle of Actium to follow her retreat - has resulted in ignominy, and is promptly retracted when she expresses her love for him, and therefore fails to effect a similar gender recuperation for him.

Apollodorus, on the other hand, expresses his love for Cleopatra through the masculine position of protector, expressed through his silent hostility towards Antony, whose gender positioning and failure to embody the paradigm leads inexorably towards disaster for both himself and Cleopatra.

Two sequences clearly underscore Apollodorus' superior performance of masculinity. Apollodorus acts as protector to Cleopatra throughout the film, but most specifically in a scene close to the end of the narrative, in which he actively seeks to cause Antony's death. Cleopatra, having ushered Caesarion out of Alexandria for his safety, has retreated to the magnificent - and secure - tomb that she has built in preparation for her death. Antony returns to the city after the complete desertion of his troops has led to an ignominious defeat against Octavian, and searches for Cleopatra in her palace. Apollodorus is waiting for Antony in Cleopatra's suite, ostensibly to pass on a message from the queen, telling Antony where she can be found, but Apollodorus deliberately delivers it so obliquely as to allow Antony to believe that Cleopatra is already dead. He then watches silently as Antony prepares to take his own life, responding to Antony's request for help with a furious, bellowed: 'I want to! But I can't!' (Mankiewicz, 1963) Only once Antony has mortally wounded himself - definitively negating any further threat he might pose to Cleopatra - does Apollodorus confess his lie, and consents to take the dying Antony to Cleopatra's tomb. 
The second instance occurs earlier in the film, but is arguably the more significant. It is essentially an extension of Antony's surrender of his cloak in Serpent of the Nile, being another instance of masculinity figuratively ceded. Having fled Actium to follow Cleopatra, Antony arrives on her ship sullen and humiliated by his inability to subordinate his love for Cleopatra to his military honour and responsibilities. Fearing that the depth of his shame might lead him to harm himself, Cleopatra - who declines to visit him in person - sends Apollodorus to take Antony's sword. The phallic symbology of the sword need hardly be stated; Apollodorus' seizure of the sword can therefore easily be read as his seizure of the exterior expression of Antony's masculinity. That he then throws it unceremoniously into the sea must therefore, by extension, be read as his symbolic triumph over Antony.

\section{'A HISTORICALLY MOBILE RELATION'}

As the boundaries of hegemonic masculinity are redefined, so Antony's performance of deficient masculinity alters to mirror the paradigm; his twenty-first century representations, for instance, evidence a growing socio-cultural tolerance for male emotional expressivity, and the paradigms of Rome, for example, are configured as paradigm precisely because they are able to express an appropriate emotional response to distressing stimuli. More recent texts have also exhibited a trend towards not simply eliding Antony's contribution to the historical record but effectively editing Antony out by reassigning his actions to other characters within the narrative. Rome is again the most explicit, positioning Vorenus alongside Caesar as he makes his way to the Senate House on the Ides of March - the loyal protector whose attention must be diverted to allow the assassins access to the dictator - and by crediting Antony's highly complex political manoeuvring in the days and hours following the assassination to Octavian instead. Such manipulations are multifaceted in both origin and potential readings, and are at least partially explicable in terms of the shift in medium from film to television that has occurred since 1999, with the concomitant shift in audience, imperative, narrative structure, and run-time. An analysis that did justice to the implications of this shift would be well outside of the remit of this paper. However, the displacement of Antony is also explicable in gender terms, evidencing, perhaps, an articulation of anxieties about men of power; of artifice, political aptitude, spin-doctors, and yes-men. The Other-ing of Mark Antony continues to provide fertile ground for the negotiation of gender anxiety, despite the fact that gender ideals remain as fluid and unstable as ever.

\section{REFERENCES:}

Note: the title quote, 'Th' abstract of all faults', is from William Shakespeare's Antony and Cleopatra, act 1, scene 4, line 8.

Belton, J. (1994) American Cinema/American Culture. New York: McGraw Hill.

Connell, R. W. (1995) Masculinities. Cambridge: Polity Press.

Buselink, J. (1988) 'Mankiewicz's Cleopatra', Films in Review, 39/1, 1 January: 7.

Daugherty, G. N. (2008) 'Her First Roman: A Cleopatra for Rome' in Cyrino, M. S. ed., Rome Season One: History Makes Television. Malden, MA: Blackwell. Chapter 11. 
Fitzgerald, W. (2001) 'Oppositions, Anxieties and Ambiguities in the Toga Movie', In: Joshel, S. R., Malamud, M., \& McGuire, D. T. eds., Imperial Projections: Ancient Rome in Modern Popular Culture. Baltimore, M.D.: The John Hopkins University Press. Chapter 1.

George, M. (1997) 'Author Note’, The Memoirs of Cleopatra. New York: St Martin’s Press.

Kelly, R. (2009) 'The Iconography of Mark Antony', Networking Knowledge: Journal of the MeCCSA Postgraduate Network, 2/1.

Schipper, M. (2006) Never Marry A Woman With Big Feet: Women in Proverbs from Around the World. Amsterdam: Amsterdam University Press

Smith, B. R. (2000) Shakespeare and Masculinity. Oxford: Oxford University Press.

Wyke, M. (2007) Julius Caesar: A Life in Western Culture. London: Granta Books.

\section{FILMOGRAPHY}

Cleopatra (1934). Directed by Cecile B. DeMille, USA, Paramount Pictures Inc.

Cleopatra (1963). Directed by Joseph L. Mankiewicz, USA, Twentieth Century Fox.

Cleopatra (1999). Directed by Franc Roddam, USA/Germany, Babelsberg International Film Produktion/Hallmark Entertainment.

Rome: Season 1 (28 Aug 2005 - 20 Nov 2005, 12 episodes). UK/USA, HD Vision Studios/British Broadcasting Corporation (BBC)/Home Box Office (HBO).

Rome: Season 2 (14 Jan 2007 - 25 Mar 2007, 10 episodes). UK/USA, HD Vision Studios/British Broadcasting Corporation (BBC)/Home Box Office (HBO).

Serpent of the Nile (1953). Directed by William Castle, USA, Columbia Pictures. 